\title{
Antioxidant activity of extracted green algae silpau (Dyctyosphaeria versluysii)
}

\author{
ENDANG S. SRIMARIANA ${ }^{1, \boldsymbol{\vartheta}}$, D.A.N. APITULEY ${ }^{2}$ \\ ${ }^{1}$ Department of Marine Science and Technology, Faculty of Fisheries and Marine Science, Bogor Agricultural University. Kampus IPB Darmaga, Jl \\ Agatis, Darmaga, Bogor 16680, West Java, Indonesia. Tel. +62-0251-8622911, /Fax. +62-0251-8622907, `email: endangsrimariana@ @mail.com \\ ${ }^{2}$ Department of Fisheries Technology, Faculty of Fisheries and Marine Sciences, Pattimura University, Kampus Poka, Jl. Chr. Soplanit, Poka, Ambon, \\ Maluku, Indonesia.
}

Manuscript received: 4 April 2019. Revision accepted: 18 August 2019.

\begin{abstract}
Srimariana ES, Apituley DAN. 2019. Antioxidant activity of extracted green algae silpau (Dyctyosphaeria versluysii). Nusantara Bioscience 11: 153-156. Silpau (Dictyosphaeria versluysii) is a green algae that is widely available in Southwest Moluccas regency, living on coral reefs and not classified as seasonal plants. Silpau has long been used by local people, generally in the form of processed vegetables or colo-colo (traditional food). Except for its nutritional value, comprehensive information about silpau still unknown. Therefore, this study was carried out to determine its potential as an antioxidant. The phytochemical content of silpau was analyzed according to the standard method. The antioxidant activity of green algae silpau extract was carried out by reducing DPPH (1,1-diphenyl-2-picrylhydrazyl) free radicals. Phytochemical test of silpau revealed that silpau contain terpenoid compounds. The result of the study showed that the $\mathrm{IC}_{50}$ value of methanol extract of silpau was $547.97 \mathrm{ppm}$, indicated that silpau methanol extract categorized as a weak antioxidant.
\end{abstract}

Keywords: Antioxidant, Dictyosphaeria versluysii, DPPH, IC 50 , silpau

\section{INTRODUCTION}

Marine macroalgae are rich in bioactive compounds that have the potential to be used as functional ingredients in human and animal health (Gupta and Ghannam 2011), as a source of alginate, carrageenan, or agar in various industries, such as the food, pharmaceutical and cosmetics industries and also has the potential as a source of natural antioxidants (Yuan et al. 2005). Antioxidants play an important role in inhibiting and scavenging radicals to protect humans against infections and degenerative diseases. Several marine algae have been reported to possess antioxidant properties (Athukorala et al. 2006). Some previous studies show that some macroalgae have the potential as antioxidants such as Padina sp. and others (Setha et al. 2013), Caulerpa racemosa var. macrophysa (Yangthong et al. 2009), Caulerpa lentillifera (Santoso et al. 2010), Padina australis (Santoso et al. 2013), Martensia fragilis (Takamatsu et al. 2003), Ecklonia cava (Heo et al. 2005), Eisenia bicyclis and Ecklonia kurome (Shibata et al. 2002), Ulva rigida (Mezghani et al. 2016), Turbinaria ornata (Deepak et al. 2017). .

Antioxidant activities are attributed to various reactions and mechanisms: prevention of chain initiation, binding of transition metal ion catalysts, reductive capacity and radical scavenging (Huang and Wang 2004). Nowadays, there is an increasing interest in natural antioxidants because of the safety and toxicity problems of synthetic antioxidants, for example, butylated hydroxyanisole (BHA) and butylated hydroxytoluene (BHT) that are commonly used in lipidcontaining food ( $\mathrm{Li}$ et al. 2007). Natural antioxidants such as $\alpha$-tocopherol, phenols and $\beta$-carotene found in higher plants are being used in the food industry to inhibit lipid peroxidation, and they can protect the human body from free radicals and retard the progress of many chronic diseases (Qi et al. 2005). Antioxidants help to prevent the free radical damage associated with the aging process.

Antioxidant activity can be tested using the DPPH method. This method is simple, easy, fast, sensitive and only requires a small sample. 1,1-diphenyl-2picrylhydrazyl (DPPH) is a free radical compound that is stable at room temperature and can be used to evaluate the antioxidant activity of several extracts of natural ingredients. Molyneux (2004) stated that DPPH could react with hydrogen atoms derived from an antioxidant to form a diphenyl-picrylhydrazine compound which is non-radical and turn pale yellow.

In Maluku waters, several marine macroalgae species have important economic values, such as Eucheuma and Hypnea as carrageenan producers, Gracilaria and Gelidium as agar-agar producers or agarophyte groups, Sargassum as alginate producers, and Porphyra is found only in the East season around April-August on the South coast of Ambon Island, usually processed into Nori. Microalgae that widely available in all districts of Southwest Maluku is silpau (Dictyosphaeria versluysii). Silpau is a green alga commonly found attaching to coral reefs and living in colonies. It is not classified as seasonal plants so that it can be consumed every day. Local communities often use silpau as a vegetable and process it into vegetable called gudangan or colo-colo (Moluccas traditional food). However, bioactivity evaluation of silpau from Southwest 
Moluccas especially as an antioxidant has not been done yet. Therefore, this research was carried out to analyze the chemical compounds and to evaluate the antioxidant activity of silpau extract.

\section{MATERIALS AND METHODS}

\section{Study area}

Silpau (Dictyosphaeria versluysii) were collected from Liti beach, Oirata Village, Kisar Island, Southwest Moluccas district. Kisar Island is one of Indonesia's outer islands located in the Wetar Strait and Timor Leste with coordinates of $8^{\circ} 6^{\prime} 10^{\prime \prime} \mathrm{S}$ and $127^{\circ} 8^{\prime} 36^{\prime \prime} \mathrm{E}$ (Figure 1).

\section{Procedures}

Material

Fresh alga silpau (Dictyosphaeria versluysii) collected from Liti beach were put in plastic bags containing seawater to prevent evaporation. In the laboratory, all of the samples were washed with seawater to clean samples from epiphyte, salt, sand, small stones, and other rubbish, then followed by washing under tap water.

\section{Preparation of sample}

After draining the existing water for one hour, fresh algae silpau was dried in an oven at $50^{\circ} \mathrm{C}$. The dried samples were cut into small pieces $(1-2 \mathrm{~cm})$ then ground with an electric mixer. The powder was stored in the refrigerator for further use.

\section{Preparation of silpau extracts}

Powder of dried silpau ( $25 \mathrm{~g}$ ) was macerated with 250 $\mathrm{mL}$ methanol for 24 hours twice. The filtrate was filtered through filter paper Whatman no 41 and placed in a glass container. Then, the filtrate was evaporated at $40^{\circ} \mathrm{C}$ using a rotary evaporator to obtain the concentrated extract. The extract was subjected to phytochemical screening for terpenoids, tannin, quinone, and anthocyanin test as described by Harborne (1987).

Antioxidant activity (DPPH free radical-scavenging activity)

Antioxidant activity assay was measured through the ability of silpau extracts on reducing the stable free radical DPPH according to the method described by Aranda et al. (2009) with some modifications. DPPH solution in methanol $(0,1 \mathrm{M})$ was prepared. The extract was prepared at the concentrations of $50 \mathrm{ppm}, 100 \mathrm{ppm}, 200 \mathrm{ppm}, 300$ ppm, 400ppm, and $500 \mathrm{ppm}$. Two $\mathrm{ml}$ of DPPH solution were added into $0.1 \mathrm{ml}$ of seaweed extract. The mixture was homogenized and incubated at room temperature for 30 minutes. The absorbance of the mixture was measured using a UV-Vis spectrophotometer at a wavelength of 517 $\mathrm{nm}$. All reactions were carried out in triplicates, and the degree of decolorization indicated the free radical scavenging activities of silpau extract. The capability of silpau extracts to scavenge the DPPH free radical was calculated by using the following equation:

Radical scavenging activity $(\%)=100 \times$ (1-the absorbance of samples / the absorbance of control)

\section{Data analysis}

Correlation between sample concentration and the percentage of inhibition of free radical was analyzed using linear regression with the line equation $\mathrm{Y}=\mathrm{a}+\mathrm{bx} \mathrm{y}$ is percentage of inhibition, $\mathrm{x}$ is concentration of extract silpau, a is intercept and b is slope (Steel and Torie 1989). The activity was expressed as $\mathrm{IC}_{50}$ (the inhibition concentration of silpau extract that scavenges $50 \%$ of DPPH free radicals). analyzed using linear regression with the line equation.

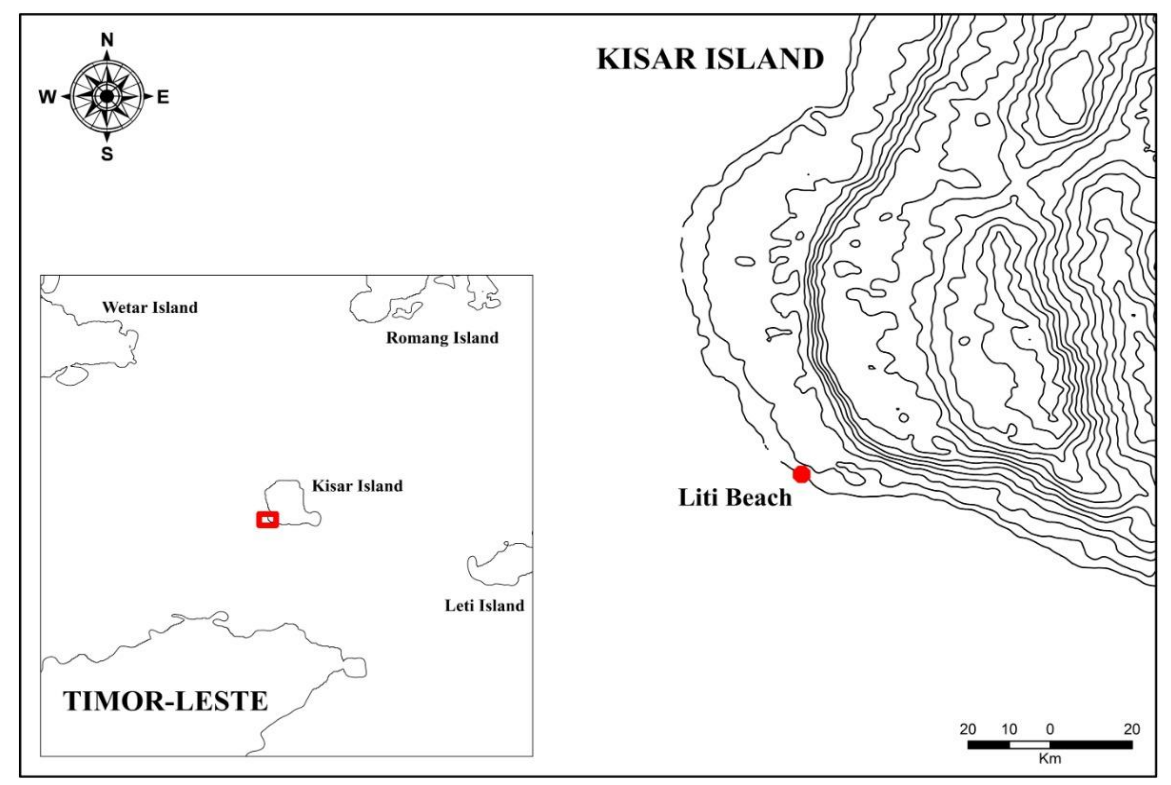

Figure 1. Map of Kisar Island in Southwest Molluccas and sampling location (red circle) 


\section{RESULTS AND DISCUSSION}

\section{Phytochemical screening of silpau methanol extract}

The results of the phytochemical screening of silpau methanol extract were presented in Table 1. It showed that silpau methanol extract contained terpenoids (Table 1).

\section{Result of DPPH radical scavenging activity of extracts silpau}

Free radical scavenging activity of silpau methanol extract can be observed through color changes from purple to turn yellow and is presented in Table 2. The highest inhibition percentage $(45.99 \%)$ was obtained from the highest concentration of silpau extract $(500 \mathrm{ppm})$ while the lowest inhibition percentage $(5.87 \%)$ obtained from the lowest concentration of silpau extract (50 ppm) (Table 2).

Linear regression analysis in order to obtained $\mathrm{IC}_{50}$ value based on the data in Table 1, and the equation was: Y $=4.299+0.0834 \mathrm{x}\left(\mathrm{R}^{2}=0.98\right)$. The determination of $\mathrm{IC}_{50}$ by entering the response value $(\mathrm{Y}=50)$ to the regression equation. The value of $\mathrm{x}$ will be obtained from the regression equation is the $\mathrm{IC}_{50}$ value. Based on the interpolation of the linear regression equation, the $\mathrm{IC}_{50}$ value of silpau methanol extract was $547.97 \mathrm{mg} / \mathrm{L}$ (Figure 2).

\section{Discussion}

Marine algae are potential sources of secondary metabolites that might be used as a lead compound in the development of new pharmaceutical agents. Secondary metabolites, including terpenes, play important ecological roles in marine organisms, especially for sessile and softbodied organisms, they face intense competition for space, reproduction, unclean surface maintenance and predatory prevention (Fusetani 2004). Therefore, marine organisms have developed bioactive secondary metabolites as a potential defensive means against competitors and/or predators. The compound of secondary metabolites of marine algae may contain alkaloids, phenols, flavonoids, saponins, steroids, terpenoids, and active metabolites that have great medicinal value (Abad et al. 2011). Recently, marine algae have been widely used in the pharmaceutical industries (Yuan et al. 2005). Much attention has been focused on the phytoconstituents of marine algal populations in different regions (Khairy and Sheik 2015).

Research on marine algae as sources of bioactive agents for the needs of pharmaceutical industries still little has been done in the eastern part of Indonesia. Most of them are utilized as sources of traditional food material. Such as green algae silpau has high nutritional value. The proximate analysis of fresh silpau conducted by Lewerissa and Srimariana (2012) showed the following results: water $89.17 \%$, ash $2.35 \%$, protein $0.8 \%$, fat $0.52 \%$, $7.09 \%$ carbohydrates, iodine $8.79 \mathrm{mg} / \mathrm{L}$, crude fiber $17.23 \%, \mathrm{Cu}$ $0.048 \mathrm{mg} / \mathrm{L}, \mathrm{Zn} 0.138 \mathrm{mg} / \mathrm{L}$, energy $36.52 \mathrm{kcal} / \mathrm{g}$. A previous study by Trono (1997) showed that silpau contained several minerals, namely $\mathrm{Cd}, \mathrm{Cu}, \mathrm{Hg}, \mathrm{Ni}, \mathrm{I}, \mathrm{Pb}$ and $\mathrm{Zn}$.
Table 1. Phytochemical screening of silpau methanol extract

\begin{tabular}{ll}
\hline Phytochemical analysis & Results \\
\hline Terpenoid & + \\
Tanin & - \\
Quinon & - \\
Antosianin & - \\
\hline Note: +: Present;- : Absent &
\end{tabular}

Note: +: Present;- : Absent

Table 2. DPPH free radical scavenging activity of silpau methanol extracts

\begin{tabular}{lllllll}
\hline \multirow{2}{*}{ Replication } & \multicolumn{6}{c}{ \% Inhibition } \\
& $\mathbf{5 0}$ & $\mathbf{1 0 0}$ & $\mathbf{2 0 0}$ & $\mathbf{3 0 0}$ & $\mathbf{4 0 0}$ & $\mathbf{5 0 0}$ \\
\hline 1 & 7.10 & 12.47 & 21.55 & 27.33 & 37.24 & 44.59 \\
2 & 6.05 & 16.80 & 21.26 & 31.53 & 37.90 & 48.25 \\
3 & 4.46 & 16.24 & 22.77 & 28.34 & 36.31 & 45.14 \\
Total & 17.61 & 45.51 & 65.58 & 87.20 & 111.45 & 137.99 \\
Average & 5.87 & 15.17 & 21.86 & 29.07 & 37.15 & 45.99 \\
\hline
\end{tabular}

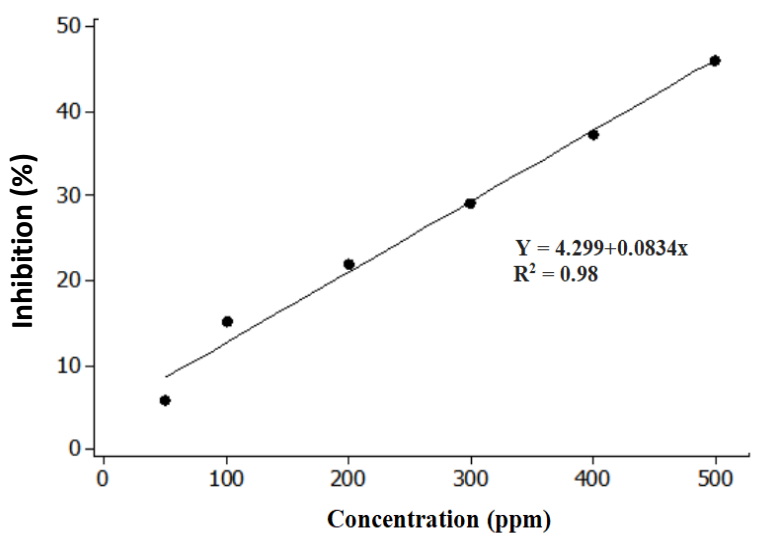

Figure 2. Antioxidant Activity of silpau methanol extracts (Dictyosphaeria versluysii)

The results of phytochemical screening of methanol extract of silpau presented in Table 1. The results showed that terpenoid was found in the silpau extracts. Terpenoids are widely distributed in nature and found abundantly in higher plants. In some marine organisms are also found terpenoids, such as marine sponges and marine algae (Abad et al. 2011). They are known to have special functions associated with other organisms related to reproduction, defense system or symbiosis (Gershenzon and Dudareva 2007; Reis et al. 2013). Terpenoids are also widely used in chemical industries, including many pharmaceuticals, flavors, fragrances, pesticides and disinfectants, and as large-volume feedstocks for chemical industries (Bohlmann and Keeling 2008).

Marine terpenoids from marine sponges show prominent bioactivities, including antimicrobial and antiviral properties (Ebada et al. 2010). These compounds have also 
been isolated from marine algae, such as red alga Peyssonnelia sp. Peyssonoic acid A and B, sesquiterpene hydroquinones, that isolated from the red alga Peyssonnelia sp., inhibited growth of Pseudoalteromonas bacteriolytic, a bacterial pathogen of marine algae, and Lindra thalassiae, a fungal pathogen of marine algae. (Lane et al. 2010). Sesquiterpenoid hydroquinones such as tiomanene and acetyl majapolene A and B isolated from Malaysian Laurencia sp, showed antimicrobial activities (Vairappan et al. 2008).

Antiviral diterpenes have also been isolated from marine algae such as diterpenes 8,10,18trihydroxy-2,6dolabelladiene and (6R)-6-hydroxydichotoma-4,14-diene1,17-dial which is isolated from Brazilian brown algae Dictyota pfaffi and Dictyota menstrualis (Abrantes et al. 2010). Besides that Cirne-Santos et al. 2008 stated that these brown algae also produced dolabellane diterpene dolabelladienetriol as a typical non-competitive inhibitor of HIV RT enzyme. Kamei et al. 2009 suggest that the diterpene sargafuran from the methanolic extract of the marine brown alga Sargassum macrocarpum, might be useful as a lead compound to develop new types of antiPropionibacterium acnes substances and new skincare cosmetics to prevent or improve acne.

Antioxidant activity was carried out by the DPPH method (Aranda et al. 2009). The principle of the DPPH method is to capture hydrogen donated by antioxidant compounds from the extracts; form reduced DPPH-H so that it becomes a stable non-radical compound (Chang et al. 2007; Molyneux 2004) or reduce free radicals (Chandini et al. 2008). The reaction is characterized by the change of a purple to pale yellow color detected at a wavelength of 517 nm.

The results of the study in Table 2 showed that the increase of extract concentration also increases the activity of free radical inhibition, which is similar with the results of a study by Kojong et al. (2010); Tanti et al. (2010); Setha et al. (2013); Khairy and Sheik (2015); and Deepak et al. (2017).

The parameters commonly used to interpret the results from $\mathrm{DPPH}$ are $\mathrm{IC}_{50}$. The $\mathrm{IC}_{50}$ value is defined as the concentration of substrate that causes $50 \%$ loss of the DPPH activity. Molyneux (2004) categorized antioxidant activity into several categories, which are very strong $\left(\mathrm{IC}_{50}\right.$ values are less than $0.05 \mathrm{mg} / \mathrm{ml}(<50 \mathrm{ppm})$, strong $\left(\mathrm{IC}_{50}\right.$ values in the range of $0.005-0.1 \mathrm{mg} / \mathrm{ml}(50-100 \mathrm{ppm})$, medium $\left(\mathrm{IC}_{50}\right.$ values in the range $0.1-0.15 \mathrm{mg} / \mathrm{ml}(100-150$ $\mathrm{ppm}$ ), weak ( $\mathrm{IC}_{50}$ values between $0.15-0.20 \mathrm{mg} / \mathrm{ml}(150-$ 200 ppm) (Molyneux 2004). The smaller $\mathrm{IC}_{50}$ meaning the higher the activity of antioxidant.

Based on the $\mathrm{IC}_{50}$ value of silpau methanol extract $(547,97 \mathrm{mg} / \mathrm{L})$, so that it can be concluded that the methanol extract of silpau categorized as a very weak antioxidant. It is probably due to the methanol extract of silpau, was not a pure compound, but still contains other compounds that probably may not have antioxidant activity. In the next study, it needs to determine antioxidant activities using different solvents, and the other bioactive compounds of silpau. It is also needed to study the antimicrobial activity and isolate antioxidant compounds from silpau extract

\section{REFERENCES}

Abad MJ, Bedoya LM, Bermejo P. 2011. Marine compounds and their antimicrobial activities. In: Méndez-Vilas A (ed.). Science against Microbial Pathogens: Communicating Current Research and Technological Advances. Formatex, Spain.

Abrantes JL, Barbosa J, Cavalcanti D, Pereira RC, Frederico Fontes CL, Teixeira VL, Moreno Souza TL, Paixao IC. 2010. The effects of the diterpenes isolated from the Brazilian brown algae Dictyota pfaffii and Dictyota menstrualis against the herpes simplex type-1 cycle. Planta Med 76: 339-344.

Aranda RS, Lopez LAP, Arroyo JL, Garza BAA, Torres NW. 2009. Antimicrobial and antioxidant activities of plants from northeast of Mexico. Evid-Based Compl Altern Med 2011: 1-6. DOI: 10.1093/ecam/nep127

Athukorala Y, Kim KN, Jeon YJ. 2006. Antiproliferative and antioxidant properties of an enzymatic hydrolysate from brown alga, Ecklonia cava. Food Chem Toxicol 44: 1065-1074.

Bohlmann J, Keeling CI. 2008. Terpenoid biomaterials. Plant J 54 (4): 656-69.

Chandini SK, Ganesan P, Bhaskar N. 2008. In vitro antioxidant activities of three selected brown seaweeds of India. Food Chem 107 (2): 707713.

Chang HY, Ho YL, Sheu MJ, Lin YH, Tseng MC, Wu SH, Huang GJ, Chang YS. 2007. Antioxidant and free radical scavenging activities of Phellinus merrillii extracts. Bot Stud 48: 407-417.

Cirne-Santos CC, Souza TM, Teixeira VL, Fontes CF, Rebello MA, Castello-Branco LR, Abreu CM, Tanuri A, Frugulhetti IC, Bou-Habib DC. 2008. The dolabellane diterpene dolabelladienetriol is a typical noncompetitive inhibitor of HIV-1 reverse transcriptase enzyme. Antivir Res 77: 64-71.

Deepak P, Sowmiya R, Balasubramani G, Perumal P. 2017. Phytochemical profiling of Turbinaria ornata and its antioxidant and antiproliferative effects. J Taibah Univ Med Sci 12 (4): 329-337.

Ebada SS, Lin WH, Proksch P. 2010. Bioactive sesterterpenes and triterpenes from marine sponges: occurrence and pharmacological significance. Mar Drugs 8: 313-346.

Fusetani N. 2004. Biofouling and antifouling. Nat Prod Rep 21: 94-104.

Gershenzon J, Dudareva N. 2007. The function of terpene natural products in the natural world. Nat Chem Biol 3: 408-414.

Gupta S, Abu-Ghannam N. 2011. Bioactive potential and possible health effects of edible brown seaweeds. Trends Food Sci Technol 22 (6): 315-326.

Harborne JB. 1984. Phytochemical Methods. Springer, Dordrecht.

Heo SJ, Park PJ, Park EJ, Kim SK, Jeon YJ. 2005. Antioxidant activity of enzymatic extracts from a brown seaweed Ecklonia cava by electron spin resonance spectrometry and comet assay. Eur Food Res Technol 221: 41-47. DOI 10.1007/s00217-005-1187-3.

Huang HL, Wang BG. 2004. Antioxidant Capacity and Lipophilic Content of Seaweeds Collected from the Qingdao Coastline. J Agric Food Chem 52 (16): 4993-4997.

Kamei Y, Sueyoshi M, Hayashi KI, Terada R, Nozaki H. 2009. The novel anti-Propionibacterium acnes compound, Sargafuran, found in the marine brown alga Sargassum macrocarpum. J Antibiot 62 (5): 259.

Khairy HM, Sheikh MAE. 2015. Antioxidant activity and mineral composition of three Mediterranean common seaweeds from Abu-Qir Bay, Egypt. Saudi J Biol Sci 22: 623-630.

Kojong N, Monintja M, Wehantouw F, Paendong E. 2010. Phytochemical analysis and free radical scavenging activity from tuis (Nicolaia speciosa, Horan). Chem Prog 3: 46-51.

Lane AL, Mular L, Drenkard EJ, Shearer TL, Engel S, Fredericq S, Aalbersberg W. 2010. Ecological leads for natural product discovery: novel sesquiterpene hydroquinones from the red macroalga Peyssonnelia sp. Tetrahedron 66 (2): 455-461.

Lewerissa S, Srimariana ES. 2012. A preliminary study of silpau (Dictyospaeria versluysii): nutritional content. Jurnal STP ( Teknologi dan Penelitian Terapan) 2: 112-123. [Indonesian]

Li HB, Cheng KW, Wong CC, Fan KW, Chen F, Jiang Y. 2007. Evaluation of antioxidant capacity and total phenolic content of different fractions of selected microalgae. Food Chem 102: 771-776. 
Mezghani S, Csupor D, Bourguiba I, Hohmann J, Amri M, Bouaziz M. 2016. Characterization of phenolic compounds of Ulva rigida (Chlorophrcae) and its antioxidant activity. Eur J Med Plants 12 (1) $1-9$.

Molyneux P. 2004. The use of stable free radical diphenyl picrilhydrazil (DPPH) for estimating antioxidant activity. Songklanakarin J Sci Technol 26 (2): 211-219.

Qi H, Zhao T, Zhang Q, Li Z, Zhao Z, Xing R. 2005. Antioxidant activity of different molecular weight sulfated polysaccharides from Ulva pertusa Kjellm (Chlorophyta). J Appl Phycol 17: 527-534.

Reis VM, Oliveira LS, Passos RMF, Viana NB, Mermelstein C, Sant'Anna C, Pereira RC, Paradas WC, Thompson FL, Amado-Filho GM, Salgado LT. 2013. Traffic of secondary metabolites to cell surface in the red alga Laurencia dendroidea Depends on a Two-Step Transport by the Cytoskeleton. PLoS One 8 (5): e63929. DOI: 10.1371/journal.pone.0063929.

Santoso J, Maulida R, Suseno SH. 2010. Aktivitas antioksidan dan ekstrak metanol, etil asetat, dan heksana rumput laut hijau Caulerpa lentillifera. Ilmu Kelautan (6) 1: 10. [Indonesian]

Santoso J, Podungge F, Sumaryanto H. 2013. Chemical composition and antioxidant activity of tropical brown algae Padina australis from Pramuka Island, District of Seribu Island, Indonesia. J Ilmu Tekn Kelautan Tropis 5 (2): 287-297. [Indonesian]

Setha B, Gaspersz FF, Idris APS, Rahman S, Mailoa MN. 2013. Potential of seaweed Padina sp. as a source of antioxidant. Intl J Sci Technol Res 2 (6): 221-224.
Shibata T, Fujimoto K, Nagayama K, Yamaguchi K, Nakamura T. 2002. Inhibitory activity of brown algal phlorotannins against hyaluronidase. Intl J Food Sci Technol 37: 703-709.

Steel RGD, Torrie JH. 1989. Prinsip dan Prosedur Statistika. Suatu Pendekatan Biometrik. Penerbit PT. Gramedia, Jakarta. [Indonesian]

Takamatsu S, Hodges TW, Rajbhandari I, Gerwick WH, Hamann MT, Nagle DG. 2003. Marine Natural Products as Novel Antioxidant Prototypes. J Nat Prod May 66 (5): 605-608.

Tanti B, Buragohain AK, Gurung L, Kakati D, Das AK, Borah SP. 2010. Assessment of antimicrobial and antioxidant activities of Dendrocnide sinuata (Blume) Chew leaves-a medicinal plant used by ethnic communities of North East India. Indian J Nat Prod Resour 1 (1): 17-21.

Trono GC. 1997. Field Guide and Atlas of the Seaweed Resources of the Philippines. AEC Graphics, Makati City.

Vairappan CS, Suzuki M, Ishii T, Okino T, Abe T, Masuda M. 2008. Antibacterial activity of halogenated sesquiterpenes from Malaysian Laurencia sp. Phytochemistry 69: 2490-2494.

Yangthong M, Towatana NH, Phromkunthong W. 2009. Antioxidant activities of four edible seaweeds from the Southern Coast of Thailand. Plant Foods Hum Nutr 64 (3): 218-223.

Yuan Y, Bone S, Carrington M. 2005. Antioxidant activity of dulse (Palmaria palmata) extracts evaluated in vitro. Food Chem 91: 485494. 